\title{
Studies on the Biosynthesis of Riboflavin
}

\section{NITROGEN METABOLISM AND FLAVINOGENESIS IN EREMOTHECIUM ASHBYII}

\author{
By T. W. GOODWIN AND S. PENDLINGTON \\ Department of Biochemistry, The University of Liverpool
}

(Received 9 March 1954)

\begin{abstract}
Many fungi are known to synthesize riboflavin in small amounts (e.g. Peltier \& Borchers, 1947, list 240 flavin-producing species), but there are three which synthesize it and excrete it into the culture medium in very large amounts. These are Candida spp. (Burkholder, 1943; Tanner, Vojnovich \& van Lanen, 1949), Eremothecium ashbyii (Guillermond, Fontaine \& Raff, 1935) and Ashbya gossypii (Wickerham, Flickinger \& Johnston, 1946).

Although many patents have been filed covering the commercial production of riboflavin using these organisms (see a review by Pridham, 1952, for full details), the observations recorded have in general been only of limited value in furthering knowledge of the basic mechanisms concerned in this biosynthesis. The main reason for this is that the cheaply available materials found to stimulate riboflavin production are generally such biochemically complex products as molasses, fish meal, hide scraps, dried blood, etc.
\end{abstract}

A considerable amount of work has been carried out in an attempt to culture $E$. ashbyii on a fully defined medium. (Schopfer, 1944; Schopfer \& Guilloud, 1945a-c; Dulaney \& Grutter, 1950; Maclaren, 1952; Yaw, 1952; Hickey, 1953), but a survey of the literature makes it clear that the problem has not yet been completely solved. Our preliminary experiments confirmed this conclusion; it was found, however, that satisfactory and reproducible growth and riboflavin synthesis could be obtained using small amounts of peptone in an otherwise synthetic culture medium. Using this type of basal medium, an investigation has been carried out on the effect of various nitrogencontaining compounds on riboflavin synthesis by $E$. ashbyii. A preliminary report of some of these findings has already been made (Goodwin \& Pendlington, 1954).

\section{EXPERIMENTAL}

Cultures. The culture used throughout this investigation was obtained from the Centraalbureau voor Schimmelcultures, Baarn, Holland. It was maintained on malt agar slopes and subcultured every 7-10 days.

Media. The basal medium used contained per 1.: glucose, 10 g.; $\mathrm{CaCl}_{2}, 0.2 \mathrm{~g}$.; $\mathrm{MgSO}_{4}, 7 \mathrm{H}_{2} \mathrm{O}, 1.0 \mathrm{~g}$.; $\mathrm{NaCl}, 0.2 \mathrm{~g}$; $\mathrm{KH}_{2} \mathrm{PO}_{4}, 2.0 \mathrm{~g}$; ; biotin $0.04 \mathrm{mg}$; thiamine, $0.1 \mathrm{mg}$.; inositol, $0.2 \mathrm{~g}$. To this was added varying amounts of bacteriological peptone (Evans) and thenitrogen compounds under test. The pH was adjusted to $5 \cdot 8$. Sterilization was carried out by autoclaving at $15 \mathrm{lb} . / \mathrm{sq}$.in. for $15 \mathrm{~min}$. Although the peptone would probably contain sufficient quantities of inositol, biotin and thiamine, it was considered advisable to add always the optimum amounts advised by Schopfer (1944). This would eliminate possible variations in the vitamin content of different batches of peptone and also the difference in vitamin levels when various concns. of peptone were being compared.

All the amino acids used except tyrosine, phenylalanine and tryptophan and all the purines and pyrimidines were obtained from L. Light \& Co. Ltd., Colnbrook, Bucks; tyrosine, phenylalanine and tryoptophan were obtained from British Drug Houses Ltd., London; 1:2-dimethyl-4amino-5-(D-1'-ribitylamino)benzene and 1:2-dimethyl-5-(Dl'-ribitylamino)benzene were the gift of Dr E. S. Holdsworth and 4:5-dimethylbenziminazole the gift of Dr V. Petrow.

Cultural conditions. The media $(15 \mathrm{ml}$.) were dispensed in Erlenmeyer flasks $(50 \mathrm{ml}$.), inoculated and incubated in a water-jacketed incubator in the dark at $28^{\circ}$ without shaking. The patent literature makes it clear that riboflavin synthesis is stimulated considerably in shake cultures. It was not possible to shake the cultures in the present investigation, but this is no drawback providing the conditions are always standardized. Each flask was inoculated with three drops of a spore suspension drawn from a 2-day-old culture grown on the basal medium plus $0.4 \%(w / v)$ peptone. This procedure was adopted following the observation of Tanner et al. (1949) that, with Ashbya gossypii, best yields of riboflavin were obtained when the inoculum vol. was about $0.5 \%$ of the total vol. of the medium and when it was obtained from young cultures. This point was not tested in $E$. ashybii, but the procedure just described was found to be extremely satisfactory and to yield very reproducible results.

Analytical procedures. Three replicate flasks were examined in each experiment. The major part of the medium and mycelium was transferred to a thin, $15 \mathrm{ml}$. tared centrifuge tube and centrifuged in a small bench centrifuge for $5 \mathrm{~min}$. A portion of the supernatant was taken for riboflavin determination and the remainder discarded; any mycelium remaining in the culture flask was transferred quantitatively to the centrifuge tube which was again spun for $5 \mathrm{~min}$. The residual medium was decanted off and the mycelium twice washed thoroughly with distilled water, followed each time by centrifuging. The washed mycelium was then dried at $80^{\circ}$ for $24 \mathrm{hr}$.

Riboflavin in the medium was determined spectrophotometrically by measuring the $E$ value of the centrifuged medium at $445 \mathrm{~m} \mu$., the wavelength of max. absorption for 
riboflavin in the visible region of the spectrum. By comparing this value with the $E_{1}^{1 \%}$. $(445 \mathrm{~m} \mu$.) value for pure riboflavin (301; Adamson, 1948), the amount of riboflavin in the medium could easily be calculated. This procedure was justified for a number of reasons: $(a)$ the starting medium exhibited almost negligible absorption at $445 \mathrm{~m} \mu$., $(b)$ the absorption spectra of different specimens of riboflavincontaining media were not significantly different from that of pure riboflavin, and (c) paper chromatography of the medium according to the method of Crammer (1948) for riboflavin and its derivatives showed that the pigment was almost entirely riboflavin; apart from riboflavin there only existed minute traces of a spot with blue fluorescence in u.v. light with an $R_{\boldsymbol{p}}$ value very close to that given by Crammer (1948) for riboflavin phosphate. The riboflavin in the mycelium was extracted by adding $10 \mathrm{ml}$. of $\mathrm{HCl}$ to the washed residue in the centrifuge tube and autoclaving at $15 \mathrm{lb} . / \mathrm{sq}$.in. for $15 \mathrm{~min}$. After cooling, the supernatant, was made up to an appropriate volume (usually $15 \mathrm{ml}$.) and the riboflavin determined spectrophotometrically. The residual mycelium was completely colourless.

\section{RESULTS \\ Reproducibility of results}

Table 1 shows twelve triplicate values obtained for riboflavin synthesis in the basal medium containing $5 \mathrm{mg}$. peptone $\mathrm{N} / 100 \mathrm{ml}$. These results were obtained over a period of 18 months and show that whilst reproducibility between flasks in any one experiment is usually excellent, the amounts of riboflavin produced under apparently identical cultural conditions at different times can vary considerably. The reason for these variations is not known, but they emphasize the need for adequate controls. The 'experimental' flasks showed the same range of variations. Occasionally (about 1 in 200 flasks), an aberrant flask is obtained, in which riboflavin synthesis is very much greater than expected, but growth is very much reduced.
Although most of the stimulatory effects dealt with in this paper are large, generally at least $50 \%$ above normal, it is obvious from Table 1 that under optimum conditions it would be possible to demonstrate significant stimulations of the order of $10-20 \%$ above normal.

\section{The effect of age on growth and riboflavin synthesis}

A typical time curve for growth and flavinogenesis by $E$. ashbyii cultured on the basal medium containing $0 \cdot 24 \%(w / v)$ peptone (Fig. 1 ), shows that growth was complete after 5 days but that riboflavin production, increasing at almost the same rate as growth during the first 5 days after inoculation, continued until about the seventh or eighth day. Thereafter, net production of riboflavin was almost nil. Following these observations, it was decided that in subsequent experiments only 5and/or 9- to 10-day cultures would be examined.

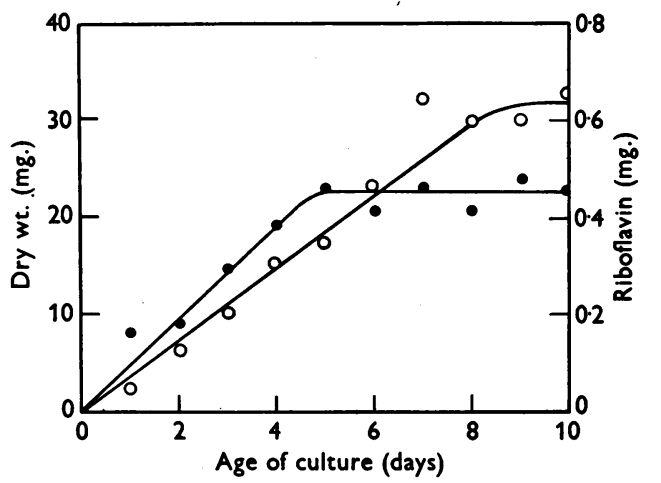

Fig. 1. Dry wt. and riboflavin production by $E$. ashbyii cultured on basal medium containing $0 \cdot 24 \%(w / v)$ peptone. Temp. $28^{\circ}$. Amounts per $15 \mathrm{ml}$. medium in $50 \mathrm{ml}$. conical flasks. $\bullet-$, dry wt.; $0-0$, riboflavin.

Table 1. Reproducibility of growth and riboflavin production by $\mathrm{E}$. ashbyii

Triplicate analyses made during different experiments; production in $15 \mathrm{ml}$. medium in $50 \mathrm{ml}$. conical flasks. Incubation time 5 days; temp. $25^{\circ}$. Basal medium $+5 \mathrm{mg}$. peptone $\mathrm{N} / 100 \mathrm{ml}$.

\begin{tabular}{|c|c|c|c|c|c|c|c|c|}
\hline \multirow{2}{*}{$\begin{array}{c}\text { Expt. } \\
\text { no. }\end{array}$} & \multicolumn{4}{|c|}{$\begin{array}{l}\text { Riboflavin } \\
\text { ( } \mu \mathrm{g} . / 15 \mathrm{ml} .)\end{array}$} & \multicolumn{4}{|c|}{$\begin{array}{l}\text { Dry wt. of mycelium } \\
\text { (mg.) }\end{array}$} \\
\hline & \multicolumn{3}{|c|}{ Individual values } & Mean & \multicolumn{3}{|c|}{ Individual values } & \multirow{2}{*}{ Mean } \\
\hline 1 & 145 & 159 & 152 & 152 & 9.8 & $9 \cdot 7$ & 9.7 & \\
\hline 2 & 122 & 177 & 170 & 156 & $11 \cdot 4$ & 12.5 & $11 \cdot 1$ & $11 \cdot 7$ \\
\hline 3 & 185 & 175 & 158 & 173 & 10.5 & 13.3 & $11 \cdot 7$ & 11.8 \\
\hline 4 & 185 & 214 & 178 & 192 & $8 \cdot 2$ & 6.9 & 7.0 & $7 \cdot 4$ \\
\hline 5 & 250 & 305 & 249 & 268 & $13 \cdot 1$ & $11 \cdot 3$ & $11 \cdot 3$ & 11.9 \\
\hline 6 & 180 & 188 & 188 & 185 & 13.6 & $12 \cdot 4$ & 14.5 & 13.5 \\
\hline 7 & 145 & 150 & 140 & 145 & 10.7 & $10 \cdot 0$ & 8.4 & 9.7 \\
\hline 8 & 106 & 102 & 111 & 106 & $12 \cdot 8$ & $12 \cdot 1$ & $12 \cdot 3$ & $12 \cdot 4$ \\
\hline 9 & 167 & 176 & 193 & 175 & - & 10.7 & 11.7 & 11.2 \\
\hline 10 & 146 & 130 & 136 & 137 & 8.6 & 10.5 & $6 \cdot 2$ & 8.4 \\
\hline 11 & 182 & 208 & 178 & 189 & 11.8 & $11 \cdot 0$ & 8.4 & $10 \cdot 4$ \\
\hline 12 & 254 & 246 & 238 & 246 & $7 \cdot 1$ & $7 \cdot 0$ & $7 \cdot 0$ & 7.0 \\
\hline
\end{tabular}




\section{The effect of the concentration of peptone}

The effect of varying the concentration of peptone was examined in the presence and absence of $0.1 \%$ (w/v) glycine. Table 2 shows that the presence of glycine had no effect on the action of peptone on riboflavin production; there does appear to have been in this case a slight stimulatory effect on growth, although this was not confirmed in other experiments (see, for example, Table 4).

Comparing Fig. 1 and Table 2, it will be seen that the observations recorded in Fig. 1, that growth but not flavinogenesis is complete after 5 days' incubation, have been confirmed.

Table 1 also indicates that the optimum concentration of peptone for riboflavin synthesis is about $0.24 \%$, if the amount per unit weight of mycelium but not the total yield is the criterion; this is most marked in 10-day cultures. Further experiments (Table 3) showed, however, that the spread is rather wide, and that the highest concentrations of riboflavin are produced over a peptone concentration range of $0 \cdot 16-0 \cdot 40 \%(w / v)$.

Table 2. Growth and riboflavin synthesis by E. ashbyii in presence and absence of glycine and in presence of varying amounts of peptone

Dry wt. and riboflavin per $15 \mathrm{ml}$. medium in $50 \mathrm{ml}$. conical flasks; basal medium described in Experimental section; temp. $28^{\circ}$.

\begin{tabular}{|c|c|c|c|c|c|c|}
\hline \multirow[b]{3}{*}{$\begin{array}{c}\text { Concn. of } \\
\text { peptone* \% } \\
(w / v)\end{array}$} & \multicolumn{3}{|c|}{ Five-day cultures } & \multicolumn{3}{|c|}{ Ten-day cultures } \\
\hline & \multirow[b]{2}{*}{$\underset{\text { (mg.) }}{\text { Dry wt. }}$} & \multicolumn{2}{|c|}{ Riboflavin } & \multirow[b]{2}{*}{$\begin{array}{c}\text { Dry wt. } \\
\text { (mg.) }\end{array}$} & \multicolumn{2}{|c|}{ Riboflavin } \\
\hline & & $\begin{array}{c}\text { Total } \\
\text { amount } \\
(\mu \mathrm{g} .)\end{array}$ & $\begin{array}{c}\text { Amount } \\
\text { (g./100 g. dry } \\
\text { mycelium) }\end{array}$ & & $\begin{array}{l}\text { Total } \\
\text { amount } \\
(\mu \mathrm{g} .)\end{array}$ & $\underset{\substack{\text { (g. } / 100 \mathrm{~g} . \mathrm{dry} \\
\text { mycelium) }}}{\text { Amount }}$ \\
\hline \multicolumn{7}{|c|}{ Medium without glycine } \\
\hline $\begin{array}{l}1.92 \\
0.96 \\
0.48 \\
0.24 \\
0.12 \\
0.06 \\
0.03\end{array}$ & $\begin{array}{r}32 \cdot 8 \\
33 \cdot 4 \\
30 \cdot 2 \\
21 \cdot 1 \\
16 \cdot 4 \\
11 \cdot 0 \\
8 \cdot 5\end{array}$ & $\begin{array}{l}904 \\
768 \\
715 \\
442 \\
465 \\
281 \\
166\end{array}$ & $\begin{array}{l}2 \cdot 76 \\
2 \cdot 32 \\
2 \cdot 41 \\
2 \cdot 25 \\
2 \cdot 82 \\
2 \cdot 99 \\
1.95\end{array}$ & $\begin{array}{r}42 \cdot 6 \\
33 \cdot 7 \\
27 \cdot 9 \\
21 \cdot 0 \\
13 \cdot 0 \\
11 \cdot 8 \\
9 \cdot 8\end{array}$ & $\begin{array}{r}1499 \\
2052 \\
1856 \\
1644 \\
1071 \\
717 \\
405\end{array}$ & $\begin{array}{l}3 \cdot 52 \\
6 \cdot 08 \\
6 \cdot 65 \\
7 \cdot 82 \\
8 \cdot 22 \\
6 \cdot 07 \\
4 \cdot 03\end{array}$ \\
\hline \multicolumn{7}{|c|}{ Medium containing glycine $1.0 \%(\mathrm{w} / \mathrm{v})$} \\
\hline $\begin{array}{l}1.92 \\
0.96 \\
0.48 \\
0.24 \\
0.12 \\
0.06 \\
0.03\end{array}$ & $\begin{array}{r}41 \cdot 4 \\
40 \cdot 1 \\
29 \cdot 0 \\
26 \cdot 1 \\
20 \cdot 8 \\
16 \cdot 0 \\
9 \cdot 1\end{array}$ & $\begin{array}{l}947 \\
799 \\
723 \\
656 \\
491 \\
282 \\
124\end{array}$ & $\begin{array}{l}2 \cdot 34 \\
2 \cdot 00 \\
2 \cdot 49 \\
2 \cdot 51 \\
2 \cdot 39 \\
1 \cdot 84 \\
1 \cdot 36\end{array}$ & $\begin{array}{l}54 \cdot 7 \\
38 \cdot 4 \\
26 \cdot 4 \\
20 \cdot 7 \\
18 \cdot 5 \\
16 \cdot 1 \\
11 \cdot 3\end{array}$ & $\begin{array}{r}1614 \\
1884 \\
1640 \\
1385 \\
1021 \\
692 \\
276\end{array}$ & $\begin{array}{l}\mathbf{2} \cdot 95 \\
\mathbf{4} \cdot 90 \\
\mathbf{6} \cdot 22 \\
\mathbf{7 \cdot 9 9} \\
\mathbf{5 \cdot 5 5} \\
\mathbf{4 \cdot 3 1} \\
\mathbf{2 \cdot 4 1}\end{array}$ \\
\hline
\end{tabular}

Table 3. Growth and riboflavin synthesis by E. ashbyii in presence of varying peptone concentrations

Dry wt. and riboflavin production per $15 \mathrm{ml}$. medium in $50 \mathrm{ml}$. conical flasks; basal medium supplemented with varying amounts of peptone.

\begin{tabular}{|c|c|c|c|c|c|c|}
\hline \multirow[b]{3}{*}{$\begin{array}{c}\text { Concn. of } \\
\text { peptone* \% } \\
(w / v)\end{array}$} & \multicolumn{3}{|c|}{ Five-day cultures } & \multicolumn{3}{|c|}{ Nine-day cultures } \\
\hline & \multirow[b]{2}{*}{$\begin{array}{c}\text { Dry wt. } \\
\text { (mg.) }\end{array}$} & \multicolumn{2}{|c|}{ Riboflavin } & \multirow[b]{2}{*}{$\underset{\text { (mg.) }}{\text { Dry wt. }}$} & \multicolumn{2}{|c|}{ Riboflavin } \\
\hline & & $\begin{array}{c}\text { Total } \\
\text { amount } \\
(\mu \mathrm{g} .)\end{array}$ & $\begin{array}{c}\text { Amount } \\
\text { (g./100 g. dry } \\
\text { mycelium) }\end{array}$ & & $\begin{array}{l}\text { Total } \\
\text { amount } \\
(\mu \mathrm{g} .)\end{array}$ & $\begin{array}{c}\text { Amount } \\
\text { (g. } / 100 \mathrm{~g} . \text { dry } \\
\text { mycelium) }\end{array}$ \\
\hline $\begin{array}{l}0.040 \\
0.080 \\
0.160 \\
0.240 \\
0.320 \\
0.400 \\
0.480\end{array}$ & $\begin{array}{l}19 \cdot 0 \\
21 \cdot 2 \\
25 \cdot 0 \\
27 \cdot 2 \\
29 \cdot 5 \\
30 \cdot 6 \\
31 \cdot 3\end{array}$ & $\begin{array}{l}185 \\
340 \\
610 \\
686 \\
725 \\
717 \\
725\end{array}$ & $\begin{array}{l}1 \cdot 01 \\
1 \cdot 45 \\
2 \cdot 42 \\
2 \cdot 52 \\
2 \cdot 45 \\
2 \cdot 35 \\
2 \cdot 32\end{array}$ & $\begin{array}{l}10.8 \\
15.6 \\
19.5 \\
25.5 \\
29.9 \\
30.3 \\
32.8\end{array}$ & $\begin{array}{r}345 \\
684 \\
1052 \\
1333 \\
1574 \\
1581 \\
1563\end{array}$ & $\begin{array}{l}\mathbf{3} \cdot 19 \\
\mathbf{4} \cdot 38 \\
\mathbf{5} \cdot 35 \\
\mathbf{5} \cdot 23 \\
\mathbf{5} \cdot 26 \\
\mathbf{5} \cdot 22 \\
\mathbf{4} \cdot 76\end{array}$ \\
\hline
\end{tabular}




\section{Effect of various amino acids on flavinogenesis}

Two control media were used: $A$ consisted of the basal medium plus peptone ( $\equiv 0.005 \%, w / v, N)$; which gave a reasonable growth (about $10 \mathrm{mg}$. dry wt. per $15 \mathrm{ml}$.) but only a comparatively small production of riboflavin. Medium $B$ consisted of the basal medium plus $0.025 \%(w / v)$ peptone $\mathrm{N}$. This gave about twice the dry weight produced by $A$ and more than twice the amount of riboflavin. By adding various $\mathrm{N}$ sources to medium $A$ in amounts calculated to bring the total $N$ content of the medium to that of $B$, the ability of the $N$ sources to stimulate the synthesis of riboflavin could be assessed and compared with that of peptone. Table 4 gives the results obtained when most of the known amino acids except tyrosine and tryptophan (see later) were examined in this way. It will be seen that most of these amino acids are incapable of stimulating either growth or flavinogenesis, whilst L-cysteine inhibited growth completely. Two amino acids, however, DL-serine and DL-threonine, specifically stimulated riboflavin production. L-Asparagine, L-aspartic acid and L-glutamic acid stimulated both growth and riboflavin production equally, as evidenced by the same concentrations of riboflavin in these cultures as in the $B$ controls. They could not, therefore, be considered to have a specific effect on riboflavin. A few amino acids (e.g. L-cystine) tended to inhibit growth slightly without affecting riboflavin synthesis. This resulted in a somewhat higher riboflavin concentration than in the control medium, but as the effect was slight by comparison with that of DL-threonine and DL-serine and, more important, because the amount of riboflavin was never greater than that in the controls, these amino acids were not examined further.

Of the two specifically stimulating amino acids, threonine was examined in more detail and it was shown (Fig. 2) that maximal stimulation was achieved with $0.5 \mathrm{mg}$. L-threonine $\mathrm{N} / 100 \mathrm{ml}$. Further experiments showed that $\mathrm{D}$-threonine was inactive but in no way inhibitory, whilst, as might have been expected, DL-threonine was (below the plateau level) one half as active as the $L$ isomer. In the presence of $25 \mathrm{mg}$. peptone $\mathrm{N} / 100 \mathrm{ml}$., the effect of L-threonine is almost obliterated, presumably because sufficient is present in the extra peptone.

The two common amino acids not included in Table 4 are L-tyrosine and L-tryptophan. They were not sufficiently soluble at the $\mathrm{pH}$ of the medium to be examined at a level of $20 \mathrm{mg}$. $\mathrm{N} / 100 \mathrm{ml}$. They were, therefore, examined at lower concentrations

Table 4. Growth and riboflavin synthesis by E. ashbyii in presence of various amino acids

Dry wt. and riboflavin production per $15 \mathrm{ml}$. medium in $50 \mathrm{ml}$. conical flasks; temp. $28^{\circ}$; media $A$ and $B$ contain the basal medium $+5 \mathrm{mg}$. $/ 100 \mathrm{ml}$. and $25 \mathrm{mg}$. $/ 100 \mathrm{ml}$. of peptone $\mathrm{N}$ respectively : other media contain $5 \mathrm{mg}$. peptone $\mathrm{N} / 100 \mathrm{ml}$. plus an amino acid at a concentration equivalent to $20 \mathrm{mg}$. $\mathrm{N} / 100 \mathrm{ml}$.

\begin{tabular}{|c|c|c|c|c|c|c|}
\hline \multirow[b]{3}{*}{ Medium } & \multicolumn{3}{|c|}{ Five-day cultures } & \multicolumn{3}{|c|}{ Ten-day cultures } \\
\hline & \multirow[b]{2}{*}{$\begin{array}{c}\text { Dry wt. } \\
\text { (mg.) }\end{array}$} & \multicolumn{2}{|c|}{ Riboflavin } & \multirow[b]{2}{*}{$\begin{array}{c}\text { Dry wt. } \\
\text { (mg.) }\end{array}$} & \multicolumn{2}{|c|}{ Riboflavin } \\
\hline & & $\begin{array}{l}\text { Total } \\
\text { amount } \\
(\mu \mathrm{g} .)\end{array}$ & $\begin{array}{l}\text { Amount } \\
\text { (g./100 g. dry } \\
\text { mycelium) }\end{array}$ & & $\begin{array}{l}\text { Total } \\
\text { amount } \\
(\mu \mathrm{g} .)\end{array}$ & $\begin{array}{c}\text { Amount } \\
\text { (g./100 g. dry } \\
\text { mycelium) }\end{array}$ \\
\hline Control $A$ & $13 \cdot 7$ & 230 & $1 \cdot 68$ & $14 \cdot 0$ & 395 & $2 \cdot 82$ \\
\hline L-Alanine & $7 \cdot 9$ & 143 & 1.82 & $9 \cdot 2$ & 365 & $\mathbf{3 \cdot 3 8}$ \\
\hline DL- $\alpha$-Amino butyric acid & $9 \cdot 6$ & 118 & 1.51 & $7 \cdot 5$ & 333 & $4 \cdot 44$ \\
\hline L-Arginine & $13 \cdot 6$ & 176 & $1 \cdot 29$ & $16 \cdot 4$ & 443 & $2 \cdot 71$ \\
\hline L-Asparagine & $27 \cdot 2$ & 506 & 1.95 & $24 \cdot 5$ & 915 & $3 \cdot 73$ \\
\hline L-Aspartic acid & $\mathbf{2 0 . 5}$ & 593 & $2 \cdot 90$ & $26 \cdot 3$ & 1025 & 3.90 \\
\hline DL-Citrulline & $14 \cdot 5$ & 253 & $1 \cdot 75$ & $13 \cdot 0$ & 540 & $4 \cdot 15$ \\
\hline L-Cysteine & & No growth & & & No growth & \\
\hline L-Cystine & $11 \cdot 1$ & 283 & $2 \cdot 58$ & $9 \cdot 7$ & $\mathbf{3 4 8}$ & $\mathbf{3} \cdot 27$ \\
\hline L-Glutamic acid & $17 \cdot 5$ & 547 & $3 \cdot 12$ & $19 \cdot 0$ & 842 & $4 \cdot 43$ \\
\hline Glycine & $13 \cdot 7$ & 141 & 1.07 & $17 \cdot 7$ & 360 & $2 \cdot 05$ \\
\hline L-Hydroxyproline & $13 \cdot 4$ & 213 & $1 \cdot 59$ & $9 \cdot 0$ & 337 & $\mathbf{3} \cdot \mathbf{7 4}$ \\
\hline DL-Histidine & $16 \cdot 9$ & 179 & 1.06 & - & - & - \\
\hline DL-Isoleucine & $15 \cdot 6$ & 166 & 1.06 & $16 \cdot 7$ & 235 & 1.45 \\
\hline L-Leucine & $15 \cdot 2$ & 190 & 1.26 & $18 \cdot 3$ & 425 & $\mathbf{2} \cdot \mathbf{3 3}$ \\
\hline L-Lysine & $13 \cdot 1$ & 192 & $1 \cdot 43$ & $13 \cdot 6$ & 368 & $2 \cdot 71$ \\
\hline DL-Methionine & $14 \cdot 8$ & 135 & 0.91 & $16 \cdot 2$ & 194 & $1 \cdot 19$ \\
\hline DL-Ornithine & $15 \cdot 8$ & 152 & 0.96 & - & - & - \\
\hline L-Phenylalanine & $10 \cdot 9$ & 114 & $1 \cdot 30$ & $13 \cdot 4$ & 288 & $2 \cdot 15$ \\
\hline L-Proline & $16 \cdot 4$ & 191 & $1 \cdot 16$ & $20 \cdot 7$ & 328 & $1 \cdot 59$ \\
\hline DL-Serine & $14 \cdot 5$ & 343 & $2 \cdot 32$ & $12 \cdot 3$ & 973 & $7 \cdot 80$ \\
\hline DL-Threonine & $10 \cdot 9$ & 428 & $3 \cdot 93$ & $13 \cdot 9$ & 865 & $6 \cdot 23$ \\
\hline L-Valine & $18 \cdot 4$ & 176 & 0.95 & $19 \cdot 5$ & 359 & $1 \cdot 84$ \\
\hline Control $B$ & $22 \cdot 6$ & 473 & $2 \cdot 11$ & $24 \cdot 3$ & 985 & $4 \cdot 06$ \\
\hline
\end{tabular}


Table 5. Growth and riboflavin synthesis by $\mathrm{E}$. ashbyii in the presence of small amounts of $\mathrm{L}$-tyrosine

Media $A$ and $B$ are the basal medium plus 5 and $13 \mathrm{mg}$. peptone N/100 ml., respectively; dry wt. and riboflavin production per $15 \mathrm{ml}$. medium in $50 \mathrm{ml}$. conical flasks; temp. $28^{\circ}$.

\begin{tabular}{|c|c|c|c|c|c|c|}
\hline \multirow[b]{3}{*}{$\begin{array}{c}\text { Concn. of } \\
\text { tyrosine added } \\
\text { (mg. } \mathbf{N} / 100 \mathrm{ml} .)\end{array}$} & \multicolumn{3}{|c|}{ Five-day cultures } & \multicolumn{3}{|c|}{ Ten-day cultures } \\
\hline & \multirow[b]{2}{*}{$\begin{array}{c}\text { Dry wt. } \\
\text { (mg.) }\end{array}$} & \multicolumn{2}{|c|}{ Riboflavin } & \multirow[b]{2}{*}{$\begin{array}{c}\text { Dry wt. } \\
\text { (mg.) }\end{array}$} & \multicolumn{2}{|c|}{ Riboflavin } \\
\hline & & $\begin{array}{c}\text { Total } \\
\text { amount } \\
(\mu \mathrm{g} .)\end{array}$ & $\underbrace{\text { my }}_{\begin{array}{c}\text { Amount } \\
\text { mycelium) }\end{array}}$ & & $\begin{array}{c}\text { Total } \\
\text { amount } \\
(\mu \mathrm{g} .)\end{array}$ & $\underbrace{}_{\begin{array}{c}\text { Amount } \\
\text { (g./100 g. dry } \\
\text { mycelium) }\end{array}}$ \\
\hline $\begin{array}{l}0 \text { (control } A \text { ) } \\
0 \cdot 5 \\
1 \cdot 0 \\
2 \cdot 0 \\
4 \cdot 0 \\
8 \cdot 0 \\
0 \text { (control } B)\end{array}$ & $\begin{array}{r}10 \cdot 8 \\
8 \cdot 3 \\
10 \cdot 7 \\
9 \cdot 7 \\
10 \cdot 4 \\
7 \cdot 2 \\
15 \cdot 1\end{array}$ & $\begin{array}{l}285 \\
262 \\
282 \\
370 \\
393 \\
465 \\
469\end{array}$ & $\begin{array}{l}2 \cdot 64 \\
\mathbf{3} \cdot 16 \\
2 \cdot 64 \\
\mathbf{3} \cdot 81 \\
\mathbf{3} \cdot 78 \\
\mathbf{6} \cdot 42 \\
\mathbf{3} \cdot 10\end{array}$ & \begin{tabular}{r|}
$8 \cdot 7$ \\
$9 \cdot 3$ \\
$8 \cdot 5$ \\
$9 \cdot 0$ \\
$9 \cdot 0$ \\
$12 \cdot 8$ \\
$15 \cdot 1$
\end{tabular} & \begin{tabular}{r|}
$\mathbf{5 4 7}$ \\
$\mathbf{4 9 2}$ \\
529 \\
$\mathbf{5 3 9}$ \\
$\mathbf{6 2 4}$ \\
$\mathbf{7 4 1}$ \\
1036
\end{tabular} & $\begin{array}{l}\mathbf{6} \cdot 29 \\
\mathbf{5} \cdot 32 \\
\mathbf{6} \cdot 24 \\
\mathbf{6} \cdot 00 \\
\mathbf{6} \cdot 99 \\
\mathbf{5 \cdot 6 7} \\
\mathbf{6} \cdot 90\end{array}$ \\
\hline
\end{tabular}

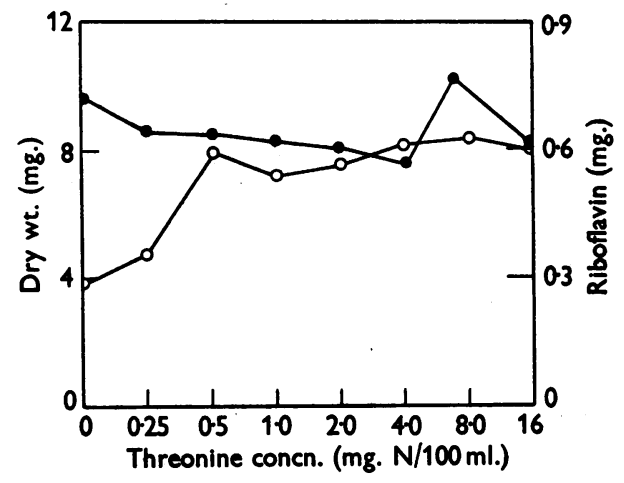

Fig. 2. The effect of the addition of varying amounts of $L-$ threonine to the basal medium plus $0.005 \%(\mathrm{w} / \mathrm{v})$ peptone $\mathrm{N}$, on dry wt. and riboflavin production. Cultural conditions are the same as described for Fig. $1 . \bullet-\bullet$ dry wt.; o-0, riboflavin.

Table 6. Growth and riboflavin synthesis by E. ashbyii in presence of small amounts of DL-phenylalanine

Media $A$ and $B$ are the basal medium plus 5 and $13 \mathrm{mg}$. peptone N/100 ml., respectively. Dry wt. and riboflavin production per $15 \mathrm{ml}$. medium in $50 \mathrm{ml}$. conical flasks; 5 day cultures; temp. $28^{\circ}$.

\begin{tabular}{|c|c|c|c|}
\hline \multirow[b]{2}{*}{$\begin{array}{c}\text { Concn. of } \\
\text { phenylalanine } \\
\text { added } \\
\text { (mg. } \mathrm{N} / 100 \mathrm{ml} \text {.) }\end{array}$} & \multirow[b]{2}{*}{$\begin{array}{c}\text { Dry wt. } \\
\text { (mg.) }\end{array}$} & \multicolumn{2}{|c|}{ Riboflavin } \\
\hline & & 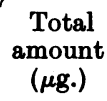 & $\underset{\text { dry mycelium) }}{\text { Amount }}$ \\
\hline $\begin{array}{l}0 \text { (control } A \text { ) } \\
0 \cdot 5 \\
1 \cdot 0 \\
2 \cdot 0 \\
4 \cdot 0 \\
8 \cdot 0 \\
0(\text { control } B \text { ) }\end{array}$ & $\begin{array}{r}11 \cdot 1 \\
8 \cdot 9 \\
8 \cdot 7 \\
9 \cdot 2 \\
9 \cdot 8 \\
7 \cdot 4 \\
18 \cdot 1\end{array}$ & $\begin{array}{l}\mathbf{3 4 7} \\
\mathbf{3 2 7} \\
\mathbf{2 8 9} \\
\mathbf{2 7 8} \\
\mathbf{3 2 0} \\
\mathbf{2 7 1} \\
\mathbf{5 7 4}\end{array}$ & \begin{tabular}{|l|l|}
$3 \cdot 19$ \\
$3 \cdot 71$ \\
$3 \cdot 32$ \\
$3 \cdot 01$ \\
$3 \cdot 28$ \\
$3 \cdot 66$ \\
$3 \cdot 35$
\end{tabular} \\
\hline
\end{tabular}

(0.5-8.0 mg. $\mathrm{N} / 100 \mathrm{ml}$.) and it was found that DLtryptophan was without effect on flavinogenesis, although growth was inhibited slightly; at the highest concentration flavinogenesis as well as growth appeared to be inhibited. L-Tyrosine, on the other hand, stimulated riboflavin synthesis, but was much less effective than threonine (Table 5). The first unequivocal response was obtained with a level of $4.0 \mathrm{mg} . \mathrm{N} / 100 \mathrm{ml}$., whilst with threonine maximal response was obtained with $0.5 \mathrm{mg}$. $\mathrm{N} / 100 \mathrm{ml}$. (Fig. 2).

The possibility existed that the weak effect of tyrosine was due to an impurity in the sample used. Paper chromatography revealed only one spot (tyrosine) and no other amino acid was detected. The presence of a trace impurity in tyrosine appears to be unlikely, for such an impurity might be expected to occur also in other amino acids, e.g. L-phenylalanine which is probably isolated from a similar source. DL-Phenylalanine was examined in more detail but with entirely negative results (Table 6).

Paper chromatography (Crammer, 1948) of the media in which riboflavin synthesis had been stimulated showed that in all cases the flavin produced was chromatographically indistinguishable from riboflavin.

\section{Effect of purines and pyrimidines}

Following the observations of Maclaren (1952) that certain purines stimulated flavinogenesis by $E$. ashbyii, a number of purines and pyrimidines and their derivatives were tested under the same conditions as were the amino acids. Table 7 shows that xanthine and adenine (as well as adenosine) specifically stimulated riboflavin considerably whilst the pyrimidines and their derivatives had no such effect. There is some inhibition of both growth 
and riboflavin synthesis with thiouracil but no specific effect on riboflavin; alloxan is very much more inhibitory than thiouracil.

More detailed examination of adenine and xanthine (Tables 8 and 9) show that xanthine tends to be somewhat more effective than adenine but that, in contrast to the observations with the flavinogenic amino acids, the stimulation continues to increase up to the highest levels examined. It will be noticed that with adenine there was no stimulation of growth even with the highest concentrations, but that with xanthine there appeared to be some growth stimulation at high concentrations.

Table 7. The effect of purines and pyrimidines. on riboflavin production by $\mathbf{E}$. ashbyii

Controls $A$ and $B$ contain the basal medium +5 and $25 \mathrm{mg}$. peptone $\mathrm{N} / 100 \mathrm{ml}$. respectively. The various purines and pyrimidines were added to $A$ in amounts equivalent to $20 \mathrm{mg}$. N/100 ml. Six-day cultures; temp. $28^{\circ}$. Amounts are those produced by $15 \mathrm{ml}$. medium in $50 \mathrm{ml}$. flasks.

\begin{tabular}{|c|c|c|c|}
\hline \multirow[b]{2}{*}{$\begin{array}{l}\text { Culture } \\
\text { medium }\end{array}$} & \multirow[b]{2}{*}{$\begin{array}{c}\text { Dry wt. } \\
\text { (mg.) }\end{array}$} & \multicolumn{2}{|c|}{ Riboflavin } \\
\hline & & $\begin{array}{c}\text { Total } \\
\text { amount } \\
(\mu \mathrm{g} .)\end{array}$ & $\underset{\substack{\text { Amount } \\
\text { (g./100 g. }}}{\text { dry mycelium) }}$ \\
\hline $\begin{array}{l}\text { Control } A \\
A \text { + adenine } \\
A \text { + adenosine } \\
A \text { + xanthine } \\
A \text { + thymine } \\
A \text { + cytosine } \\
A \text { + uracil } \\
A \text { + thiouracil } \\
A \text { + alloxan } \\
\text { Control } B\end{array}$ & \begin{tabular}{r|}
$13 \cdot 0$ \\
$11 \cdot 4$ \\
$12 \cdot 7$ \\
$13 \cdot 7$ \\
$10 \cdot 8$ \\
$11 \cdot 5$ \\
$12 \cdot 1$ \\
$7 \cdot 0$ \\
$1 \cdot 4$ \\
$22 \cdot 8$
\end{tabular} & \begin{tabular}{r|}
290 \\
572 \\
644 \\
788 \\
187 \\
301 \\
228 \\
169 \\
32 \\
685
\end{tabular} & $\begin{array}{l}2 \cdot 23 \\
5 \cdot 02 \\
5 \cdot 06 \\
5 \cdot 76 \\
1 \cdot 73 \\
2 \cdot 63 \\
1 \cdot 88 \\
2 \cdot 46 \\
2 \cdot 27 \\
3 \cdot 00\end{array}$ \\
\hline
\end{tabular}

Table 8. The effect of varying concentrations of adenine on riboflavin synthesis by $\mathbf{E}$. ashbyii

Media $A$ and $B$ contain the basal medium +5 and $45 \mathrm{mg}$. peptone $\mathrm{N} / 100 \mathrm{ml}$. respectively; 5-day culture; temp. $28^{\circ}$. Amounts produced in $15 \mathrm{ml}$. medium in $50 \mathrm{ml}$. conical flasks.

\begin{tabular}{|c|c|c|c|}
\hline $\begin{array}{c}\text { Concn. of } \\
\text { adenine added } \\
(\mathrm{mg} . \mathrm{N} / 100 \mathrm{ml} .)\end{array}$ & $\begin{array}{c}\text { Dry wt. } \\
\text { (mg.) }\end{array}$ & $\begin{array}{l}\text { Total } \\
\text { amount } \\
(\mu \mathrm{g} .)\end{array}$ & $\begin{array}{c}\text { Amount } \\
\text { (g./100 g. } \\
\text { dry mycelium) }\end{array}$ \\
\hline $\begin{array}{l}0 \text { (control } A \text { ) } \\
0 \cdot 25 \\
0 \cdot 50 \\
1 \cdot 0 \\
2 \cdot 0 \\
4 \cdot 0 \\
8 \cdot 0 \\
16 \cdot 0 \\
20 \cdot 0 \\
30 \cdot 0 \\
40 \cdot 0 \\
0 \text { (control } B \text { ) }\end{array}$ & $\begin{array}{l}11 \cdot 3 \\
10 \cdot 4 \\
11 \cdot 3 \\
10 \cdot 6 \\
11 \cdot 8 \\
11 \cdot 4 \\
10 \cdot 6 \\
12 \cdot 0 \\
12 \cdot 6 \\
12 \cdot 8 \\
11 \cdot 3 \\
21 \cdot 5\end{array}$ & $\begin{array}{l}215 \\
223 \\
304 \\
344 \\
362 \\
\mathbf{4 2 2} \\
\mathbf{4 4 2} \\
\mathbf{4 9 5} \\
\mathbf{5 6 2} \\
\mathbf{5 9 7} \\
\mathbf{7 2 0} \\
\mathbf{5 7 6}\end{array}$ & $\begin{array}{l}1 \cdot 90 \\
2 \cdot 14 \\
2 \cdot 69 \\
3 \cdot 25 \\
3 \cdot 07 \\
3 \cdot 70 \\
4 \cdot 17 \\
4 \cdot 13 \\
4 \cdot 46 \\
4 \cdot 66 \\
6 \cdot 37 \\
2 \cdot 68\end{array}$ \\
\hline
\end{tabular}

It was also found that even in the presence of $25 \mathrm{mg}$. peptone $\mathrm{N} / 100 \mathrm{ml}$. small amounts of the purines stimulated riboflavin synthesis. For example, in one experiment the addition of $8 \mathrm{mg}$. adenine $\mathrm{N} / 100 \mathrm{ml}$. increased flavinogenesis by $36 \%$.

Table 9. The effect of varying concentrations of xanthine on riboflavin synthesis by E. ashbyii

Experimental conditions as outlined in Table 8.

\begin{tabular}{|c|c|c|c|}
\hline \multirow[b]{2}{*}{$\begin{array}{l}\text { Concn. of } \\
\text { xanthine added } \\
\text { (mg. } \mathrm{N} / 100 \mathrm{ml} .)\end{array}$} & \multirow[b]{2}{*}{$\begin{array}{l}\text { Dry wt. } \\
\text { (mg.) }\end{array}$} & \multicolumn{2}{|c|}{ Riboflavin } \\
\hline & & $\begin{array}{l}\text { Total } \\
\text { amount } \\
(\mu \mathrm{g} .)\end{array}$ & $\begin{array}{c}\text { Amount } \\
\text { (g./100 g. } \\
\text { dry mycelium) }\end{array}$ \\
\hline 0 (control $A)$ & $15 \cdot 9$ & 366 & $2 \cdot 29$ \\
\hline 0.25 & $13 \cdot 7$ & 401 & $2 \cdot 92$ \\
\hline 0.50 & $13 \cdot 6$ & 437 & $3 \cdot 22$ \\
\hline $1 \cdot 0$ & $15 \cdot 0$ & 512 & $3 \cdot 40$ \\
\hline $2 \cdot 0$ & $15 \cdot 9$ & 708 & $4 \cdot 42$ \\
\hline $4 \cdot 0$ & $14 \cdot 4$ & 699 & $4 \cdot 86$ \\
\hline $8 \cdot 0$ & $18 \cdot 1$ & 722 & $3 \cdot 98$ \\
\hline $16 \cdot 0$ & $17 \cdot \overline{8}$ & 962 & $5 \cdot 38$ \\
\hline $20 \cdot 0$ & $21 \cdot 1$ & 995 & $4 \cdot 84$ \\
\hline $30 \cdot 0$ & $18 \cdot 9$ & 1137 & $6 \cdot 04$ \\
\hline $40 \cdot 0$ & \multicolumn{3}{|c|}{$\begin{array}{l}\text { (Not examined-xanthine not } \\
\text { sufficiently soluble) }\end{array}$} \\
\hline 0 (control $B$ ) & $30 \cdot 6$ & 770 & $2 \cdot 52$ \\
\hline
\end{tabular}

Table 10. The effect of uracil on growth and riboflavin synthesis by $\mathbf{E}$. ashbyii

The control is the basal medium $+0.005 \mathrm{~g}$. peptone $\mathrm{N} / 100 \mathrm{ml}$. 5-day cultures; amounts produced in $15 \mathrm{ml}$ medium in $50 \mathrm{ml}$. conical flasks; temp. $28^{\circ}$.

$\begin{array}{cccc}\begin{array}{c}\text { Amount of } \\ \text { uracil added } \\ \text { to medium } \\ \text { (mg. N/100 ml.) }\end{array} & \begin{array}{c}\text { Dry wt. } \\ \text { (mg.) }\end{array} & \begin{array}{c}\text { Total } \\ \text { amount } \\ (\mu \mathrm{g} .)\end{array} & \begin{array}{c}\text { Amount } \\ \text { (g./100 g. } \\ \text { dry mycelium) }\end{array} \\ 0 \text { (control) } & 10.8 & 262 & 2.43 \\ 50 & 8.0 & 92 & 1.03 \\ 150 & 10.2 & 130 & 1.28 \\ 200 & 11.6 & 121 & 1.04 \\ 250 & 9.5 & 161 & 1.69\end{array}$

Table 11. The effect of uracil on the adeninestimulated synthesis of riboflavin by $\mathrm{E}$. ashbyii

Control medium is basal medium $+0.005 \%(w / v)$ peptone N; 5-day cultures; amounts produced by $15 \mathrm{ml}$. medium in $50 \mathrm{ml}$. conical flasks; temp. $28^{\circ}$.

\begin{tabular}{|c|c|c|c|c|}
\hline \multirow{2}{*}{\multicolumn{2}{|c|}{ 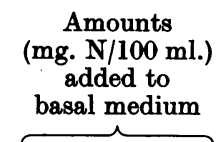 }} & \multirow{3}{*}{$\underset{\text { (mg.) }}{\text { Dry wt. }}$} & \multicolumn{2}{|c|}{$\underbrace{\text { Riboflavin }}$} \\
\hline & & & \multirow{2}{*}{$\begin{array}{l}\text { Total } \\
\text { amount } \\
(\mu \mathrm{g} .)\end{array}$} & \multirow{2}{*}{$\begin{array}{c}\text { Amount } \\
\text { (g./100 g. } \\
\text { dry mycelium) }\end{array}$} \\
\hline Adenine & Uracil & & & \\
\hline 0 & 0 & $9 \cdot 7$ & 145 & 1.50 \\
\hline 4 & 0 & $9 \cdot 6$ & 252 & $2 \cdot 71$ \\
\hline 4 & 2 & $12 \cdot 6$ & 280 & $2 \cdot 2$ \\
\hline 4 & 4 & $10 \cdot 8$ & 254 & $2 \cdot 4$ \\
\hline 4 & 8 & $11 \cdot 7$ & 229 & $2 \cdot 0$ \\
\hline 4 & 16 & $11 \cdot 2$ & 210 & 1.9 \\
\hline
\end{tabular}


The results given in Table 7 indicated that uracil had only a doubtful inhibitory effect on riboflavin synthesis when tested at a low concentration com. pared with that used by Maclaren (1952), who obtained marked inhibition. Uracil was accordingly tested under our conditions at the levels employed by Maclaren. It will be seen (Table 10) that at concentrations of $50 \mathrm{mg} . \mathrm{N} / 100 \mathrm{ml}$. and above very little effect on growth was observed but that flavinogenesis was inhibited to the extent of about $50 \%$. If, as Maclaren suggested, uracil exerts its inhibitory action by blocking the incorporation of a purine into the riboflavin molecule, then this effect should be most marked under conditions where purines would normally be stimulating riboflavin synthesis. Table 11 shows that under these conditions using adenine as the purine, there was only very slight inhibition even when the uracil concentration was 4 times that of adenine.

\section{Effect of derivatives of 4:5-dimethyl-o-phenylenediamine}

Other nitrogeneous compounds which might be precursors of riboflavin are. 5:6-dimethylbenziminazole and 1:2-dimethyl-4-amino-5-(D-1'-ribitylamino)benzene. These, together with 1:2-dimethyl5-(D-1'-ribitylamino)benzene, have been examined in the same way as the previous compounds at a level equivalent to the level of adenine (4 mg. $\mathrm{N} / 100 \mathrm{ml}$.) used in previous experiments. The results of one of these experiments are recorded in Table 12. No stimulation was observed and in fact there was in two cases slight but definite inhibition. This inhibition has been confirmed in other experiments (see, for example, Table 14).

\section{Miscellaneous nitrogen compounds}

A number of other nitrogeneous compounds have also been examined and the results of one such experiment are recorded in Table 13. It will be seen that glucosamine considerably inhibits both growth and riboflavin synthesis equally, whilst $\left(\mathrm{NH}_{4}\right)_{2} \mathrm{SO}_{4}$ is without obvious effect. Urea is interesting in that in all experiments at the higher level it has proved non-stimulatory for riboflavin; at the lower level, on the other hand, it is occasionally slightly stimulatory, as in the experiment recorded in Table 13. The reason for this spasmodic stimulation is not known.

\section{Combined effect of various nitrogen sources}

The effect on riboflavin synthesis of the addition of other nitrogeneous substances to a medium containing L-threonine at its optimum level has been examined. In the results set out in Fig. 3, riboflavin production is recorded as the percentage stimulation above the control level. It was not considered necessary to record the dry weights of the mycelia, although they were measured, because, as shown earlier, none of the substances examined

Table 12. The effect of 4:5-dimethyl-o-phenylenediamine derivatives on riboflavin synthesis by $\mathbf{E}$. ashbyii

Control medium is basal medium $+0.005 \%(\mathrm{w} / \mathrm{v})$ peptone $\mathrm{N}$; 5 -day cultures; amounts produced by $15 \mathrm{ml}$. medium in $50 \mathrm{ml}$. conical flasks; temp. $28^{\circ}$.

\begin{tabular}{|c|c|c|c|c|}
\hline \multirow{2}{*}{ Compound tested } & \multirow[b]{2}{*}{$\begin{array}{l}\text { Amount } \\
\text { added* } \\
\text { (mg./100 ml.) }\end{array}$} & \multirow[b]{2}{*}{$\begin{array}{c}\text { Dry wt. } \\
\text { (mg.) }\end{array}$} & \multicolumn{2}{|c|}{ Kibonavin } \\
\hline & & & $\begin{array}{l}\text { Tọtal } \\
\text { amount } \\
(\mu \mathrm{g} .)\end{array}$ & $\begin{array}{l}\text { Amount } \\
\text { (g./100 g. dry } \\
\text { mycelium) }\end{array}$ \\
\hline $\begin{array}{l}0 \text { (control) } \\
\text { 5:6-Dimethylbenziminazole } \\
\text { 1:2-Dimethyl-4-amino-5-(D-1'-ribitylamino)benzene } \\
\text { 1:2-Dimethyl-5-(D-1'-ribitylamino)benzene }\end{array}$ & $\begin{array}{l}0 \\
\mathbf{7 \cdot 4} \\
\mathbf{3} \cdot \mathbf{9} \\
\mathbf{4} \cdot \mathbf{1}\end{array}$ & $\begin{array}{r}10 \cdot 4 \\
9 \cdot 8 \\
10 \cdot 1 \\
10 \cdot 2\end{array}$ & $\begin{array}{l}175 \\
126 \\
148 \\
178\end{array}$ & $\begin{array}{l}1 \cdot 68 \\
1 \cdot 28 \\
1 \cdot 46 \\
1 \cdot 74\end{array}$ \\
\hline
\end{tabular}

* These amounts are the molecular equivalents of $7 \cdot 7 \mathrm{mg}$. adenine, which contains $4.0 \mathrm{mg}$. $\mathrm{N}$.

Table 13. The effect of some miscellaneous nitrogenous compounds on riboflavin synthesis by $\mathbf{E}$. ashbyii

Control media $A$ and $B$ contain the basal constituents +5 and $25 \mathrm{mg}$. peptone N/100 ml. respectively. Amounts produced by $15 \mathrm{ml}$. of medium in $50 \mathrm{ml}$. conical flasks; temp. $28^{\circ}$; 5-day cultures.

\begin{tabular}{|c|c|c|c|c|}
\hline $\begin{array}{l}\text { Constituent } \\
\text { added to medium }\end{array}$ & $\begin{array}{l}\text { Concentration } \\
\text { of constituent } \\
\text { (mg. N/100 ml.) }\end{array}$ & $\begin{array}{c}\text { Dry wt. } \\
\text { (mg.) }\end{array}$ & $\begin{array}{c}\text { Total } \\
\text { amount } \\
(\mu \mathrm{g} .)\end{array}$ & $\begin{array}{c}\text { Amount } \\
\begin{array}{c}\text { (g./100 g. dry } \\
\text { mycelium) }\end{array}\end{array}$ \\
\hline $\begin{array}{l}0 \text { (control } A \text { ) } \\
\text { Glucosamine } \\
\text { Urea } \\
\text { Urea } \\
\left(\mathrm{NH}_{4}\right)_{2} \mathrm{SO}_{4} \\
\left(\mathrm{NH}_{4}\right)_{2} \mathrm{SO}_{4}\end{array}$ & $\begin{array}{r}0 \\
20 \\
5 \\
20 \\
10 \\
20\end{array}$ & $\begin{array}{r}11 \cdot 3 \\
4 \cdot 8 \\
10 \cdot 0 \\
11 \cdot 9 \\
9 \cdot 6 \\
9 \cdot 9\end{array}$ & $\begin{array}{r}213 \\
70 \\
297 \\
241 \\
239 \\
228\end{array}$ & $\begin{array}{l}1 \cdot 89 \\
1 \cdot 52 \\
2 \cdot 97 \\
2 \cdot 03 \\
2 \cdot 49 \\
2 \cdot 31\end{array}$ \\
\hline
\end{tabular}


has any obvious effect on the growth of the organism. Fig. 3 shows that the addition of the other stimulatory amino acids DL-serine and L-tyrosine did not enhance the effect due to $\mathrm{L}$-threonine alone and that urea and $\left(\mathrm{NH}_{4}\right)_{2} \mathrm{SO}_{4}$ were also inactive. The addition of the purine adenine, however, enhanced the $L$ threonine effect and produced more riboflavin than could be expected from a simple summation of the increases obtained when these two substances were tested separately.

Similar experiments carried out using the basal medium containing $4 \mathrm{mg}$. adenine $\mathrm{N} / 100 \mathrm{ml}$. and to which other nitrogen sources were added, again showed (Fig. 4) the extra stimulation in the presence of L-threonine and demonstrated that DLserine was equally effective. Some stimulation was

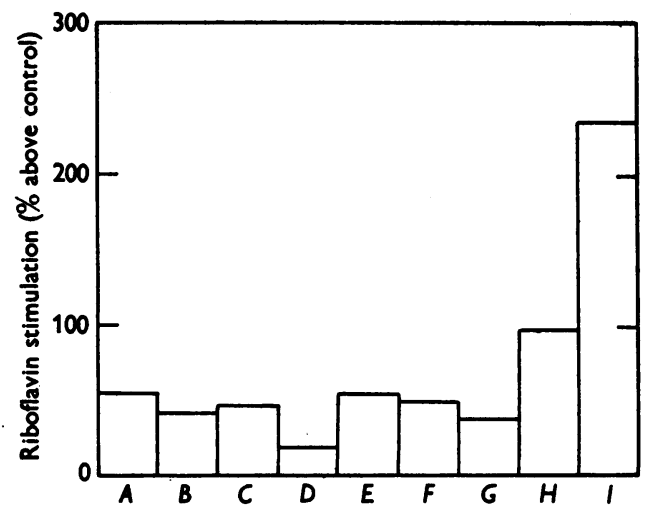

Fig. 3. The combined effect of $L$-threonine and one other $N$ source on riboflavin synthesis. Results are expressed as \% increase over production on the basal medium plus $0.005 \%(\mathrm{w} / \mathrm{v})$ peptone $\mathrm{N}$. Cultural conditions as described in Fig. 1. $A$, L-threonine alone (1 mg. $\mathrm{N} / 100 \mathrm{ml}$.); $B$, DL-serine alone (10 mg. $\mathrm{N} / 100 \mathrm{ml}$ ); $C, A+B ; D$, Ltyrosine alone (5 mg. N/100 ml.); $E, A+D ; F, A+$ urea* (5 mg. N/100 ml.); $G, A+\left(\mathrm{NH}_{4}\right)_{2} \mathrm{SO}_{4}{ }^{*}(10 \mathrm{mg} . \mathrm{N} / 100 \mathrm{ml}$.); $H$, adenine alone (4 mg. $\mathrm{N} / 100 \mathrm{ml}$ ); $I, A+H$.

* $\left(\mathrm{NH}_{4}\right)_{2} \mathrm{SO}_{4}$ alone is without stimulatory action, whilst urea alone has a slight effect (Table 10). also obtained with urea and to a slight extent with L-tyrosine, whilst $\left(\mathrm{NH}_{4}\right)_{2} \mathrm{SO}_{4}$ was completely inactive.

It was thought that the failure of 5:6-dimethylbenziminazole and 1:2-dimethyl-4-amino-5-(D-1'. ribitylamino)benzene to stimulate riboflavin synthesis might be due to the absence of the appropriate coupling compound (e.g. alloxan). Consequently, they were tested in the presence of small noninhibitory amounts of alloxan (4 mg. N/100 ml.) and adenine $(4 \mathrm{mg} . \mathrm{N} / 100 \mathrm{ml}$.) and DL-threonine ( $2 \mathrm{mg}$. $\mathrm{N} / 100 \mathrm{ml}$.). In the first case there was no stimulation of riboflavin synthesis and in the latter there was no potentiation of the adenine and threonine effects.

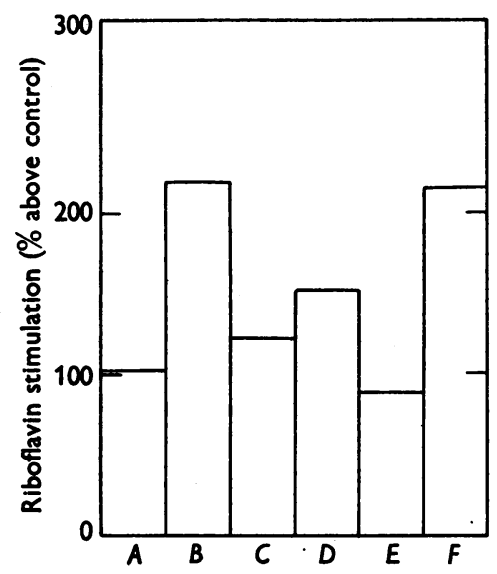

Fig. 4. The combined effect of the addition of adenine and one other $\mathbf{N}$ source on riboflavin synthesis. Results expressed as described in Fig. 3 and experimental conditions as described in Fig. 1. $A$, adenine alone $(8 \mathrm{mg}$. $\mathrm{N} / 100 \mathrm{ml}$.); $B, A+$ L-threonine* $(1 \mathrm{mg} . \mathrm{N} / 100 \mathrm{ml}$.); $C, A+$ L-tyrosine* (5 mg. N/100 ml.); $D, A+$ urea* $^{*} 5 \mathrm{mg}$. $\mathrm{N} / 100 \mathrm{ml}.) ; \quad E, A+\left(\mathrm{NH}_{4}\right)_{2} \mathrm{SO}_{4}^{*}(10 \mathrm{mg} . \mathrm{N} / 100 \mathrm{ml}$.); $F, A+$ DL-serine* (10 mg. N/100 ml.).

* For control values of the additional $\mathrm{N}$ source values see Fig 3 and Table 13.

Table 14. The relative amounts of riboflavin in mycelium and medium

Amounts produced in $15 \mathrm{ml}$. medium in $50 \mathrm{ml}$. conical flasks. Incubation time, 5 days; temp. $28^{\circ}$.

Riboflavin

\section{Medium}

$A^{*}$ (basal medium $+5 \mathrm{mg}$. peptone $\mathrm{N} / 100 \mathrm{ml}$.)

$B^{*}$ (basal medium $+5 \mathrm{mg}$. peptone $\mathrm{N} / 100 \mathrm{ml}$.)

$A+$ DL-threonine (2 mg. N/100 ml.)

$A$ +adenine (4 mg. N/100 ml.)

$B+$ glycine $(20 \mathrm{mg}$. N/100 ml.)

$B+5: 6$-dimethylbenziminazole

$B+1: 2$-dimethyl-5-(D-1'-ribitylamino)benzene

$B+1: 2$-dimethyl-4-amino-5-(D-1'-ribitylamino)benzene

$\begin{array}{cccc}\text { In mycelium } \\ \begin{array}{c}(\mu \mathrm{g} .) \\ 131\end{array} & \begin{array}{c}\text { In medium } \\ (\mu \mathrm{g} .)\end{array} & \begin{array}{c}\text { Total } \\ (\mu \mathrm{g} .)\end{array} & \begin{array}{c}\text { \% of total } \\ \text { in mycelium }\end{array} \\ 100 & 181 & 312 & 41 \cdot 7 \\ 168 & 165 & 265 & 37 \cdot 8 \\ 153 & 263 & 431 & 39 \cdot 0 \\ 59 & 297 & 450 & 34 \cdot 0 \\ 78 & 115 & 174 & 34 \cdot 0 \\ 82 & 119 & 197 & 39 \cdot 6 \\ 87 & 188 & 270 & 30 \cdot 4 \\ & 137 & 224 & 26 \cdot 9\end{array}$

* $A$ and $B$ are the same medium but the two series of experiments were carried out at different times. 


\section{Riboflavin in the mycelium}

According to Deseive (1947) the mycelial riboflavin (which is mainly in the form of flavin-adenine dinucleotide (Forrest, private communication)) in $E$. ashbyii is negligible compared with that in the medium. On checking this under our conditions this was found not to be so. Table 14 shows that about $30-40 \%$ of the total riboflavin produced is in the mycelium. The possibility that the increased riboflavin observed in the medium in the presence of threonine, serine and purines might be due to the liberation of mycelial riboflavin into the medium is ruled out by the demonstration (Table 14) that in the presence of these stimulators the mycelial riboflavin is also increased, but not to the same extent as is the riboflavin in the medium. The results in Table 14 also show that the failure of glycine (which might be expected to be active because of its possible conversion into serine), 5:6-dimethylbenziminazole and 1:2-dimethyl-4-amino-5-(D-1'. ribitylamino)benzene to stimulate riboflavin synthesis is not due to the failure to release riboflavin from the mycelium into the medium.

\section{DISCUSSION}

\section{Comparison with earlier work on amino acid utilization}

It is somewhat difficult to compare the results of the present amino acid experiments with those of other investigators (Schopfer \& Guilloud, 1945 $b$; Chin, 1947; Deseive, 1947; Hickey, 1953) because the experimental conditions were so different and, apart from Hickey, none of these investigators examined either serine or threonine. In Hickey's experiments they were examined in culture media in which they were the sole source of nitrogen, and, as might be expected from the present work, they did not support growth of the organism.

In agreement with Chin (1947) and Hickey (1953) it has been found that asparagine, aspartate and glutamate were good nitrogen sources for both growth and riboflavin synthesis, and it is difficult to explain the results of Schopfer \& Guilloud (1945b) which indicated that no growth or riboflavin was produced on aspartate or glutamate.

The present work confirms the observations of Deseive (1947) that L-cysteine inhibits considerably growth and flavinogenesis.

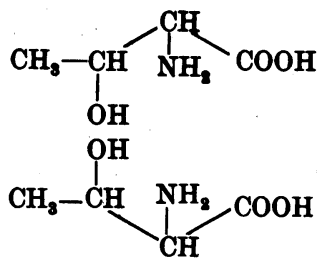<smiles>[R]n1cnc2c(=O)[nH]c(=O)[nH]c21</smiles>

It is interesting that in the present experiments glycine had little if any effect on growth of $E$. ashbyii and these results tend to confirm those of Dulaney \& Grutter (1950), who concluded that glycine was not utilized by this organism. Schopfer (1944), on the other hand, found that glycine stimulated growth in the presence of some samples of peptone and not in others. Most of the amino acids fall into the same category as glycine, but it ought to be emphasized that it is not necessarily true that they are not metabolized by $E$. ashbyii. If, for example, growth alone had been the criterion, then L-threonine would have been considered inert.

\section{Role of amino acids and purines in biosynthesis of riboflavin}

The most likely explanation of the stimulation of riboflavin synthesis in $E$. ashbyii by certain amino acids and purines is that they are sources of specifio building units which, under the prescribed experimental conditions, are limiting factors. It is possible, however, that the effect might be indirect and, although this appears unlikely, it remains for isotope studies, at present in progress, to decide this unequivocally. There is, however, some evidence that in the closely related organism $A$. gossypii, the biosynthesis of riboflavin follows a very similar course to that of the purines. Recent work by Plaut $(1953 a)$ with this organism has shown that ${ }^{14} \mathrm{C}$ labelled formate and $\mathrm{CO}_{2}$ are incorporated almost entirely into $\mathrm{C}_{2}$ and $\mathrm{C}_{4}$ of riboflavin respectively. This agrees with the present views on the incorporation of these units into purines (see, for example, Brown, 1953). The position of glycine which is specifically incorporated into purines but which does not under our conditions stimulate riboflavin production appears to be somewhat anomalous. There is, however, no reason to believe that because it does not stimulate riboflavin synthesis it cannot be incorporated into the molecule, and very recently Plaut (1953b) has shown that incorporation can take place.

Assuming then the incorporation of the stimulatory amino acids and purines into riboflavin, many interesting possibilities arise. The fact that the amino acid stimulations are not cumulative suggests that they probably provide the same building unit. As the effect of amino acid plus purine is cumulative, the biosynthesis could be envisaged, using threonine and xanthine as examples, formally as follows:<smiles>[R]n1c2nc(=O)[nH]c(=O)c-2nc2cc(C)c(CC)cc21</smiles> 
On this scheme the amino acids function only by providing a carbon source, which is incorporated into the aromatic moiety of riboflavin. It is obvious that threonine and serine must provide the same or closely related units. It is not yet known whether the slight activity of tyrosine is possibly due to a limited ability of the fungus to split off serine from the molecule.

The observation that the addition of purine to a medium containing optimum amounts of $L$ threonine produces an effect greater than the sum of the two separate effects suggests that stimulation by L-threonine alone ceases at a low concentration because purines or their immediate precursors become the limiting factors. Addition of a purine results in the utilization of the remainder of the L-threonine and also in the stimulation of flavin biosynthesis due to the utilization of the purine itself; this is possible, for the conversion of purine into riboflavin is, even at low concentrations, only of the order of $20-30 \%$.

The fact that stimulation by purines alone does not stop at a comparatively low concentration but continues to increase even up to the highest concentration (a saturated solution) examined, would suggest that in the basal medium there is no shortage of 'aromatic precursors' such as may be provided by threonine. It could, however, also be ascribed to the fact that some of the purine is catabolized thereby yielding 'aromatic precursors'. It is, for example, possible from purely structural considerations, to envisage the release of serine.

A number of questions arise when the role of purines in flavinogenesis is further considered. They can only be solved by further work but may be briefly enumerated here: $(a)$ although it is apparent that adenine can be deaminated, does this occur before or after incorporation into the riboflavin molecule? $(b)$ is the ribose of adenosine removed or reduced to ribitol before incorporation of the purine? and $(c)$ if 6:7-dimethylisoalloxazine is first formed, is ribose attached and then reduced or is ribitol itself attached?

\section{Role of o-phenylenediamine derivatives and pyrimidines in riboflavin biosynthesis}

It is evident from this work that pyrimidines are not specifically incorporated into riboflavin, even in the presence of urea which, theoretically, could supply the unit for converting a pyrimidine into a purine. (The reason for the slight sporadic stimulation of urea alone is not yet obvious.) It has been found that in high concentration uracil actually inhibits riboflavin synthesis. This is in agreement with the original observations of Maclaren (1952), but we could not obtain as great an inhibition (50\% compared with $83 \%$ ). As it was found that the stimulatory power of adenine was reduced only slightly, in the presence of a considerable excess of uracil, Maclaren's suggestion that uracil may act by competitively inhibiting the incorporation of purines into the riboflavin molecule may not be correct.

The failure of 1:2-dimethyl-4-amino-5-(D-1' ribitylamino)benzene (I) to stimulate the synthesis of riboflavin alone or in the presence of non-toxic amounts of alloxan strongly suggests that a biosynthetic pathway similar to the chemical synthesis of Banerjee, Dittmer \& du Vigneaud (1945) involving the condensation of $(I)$ with alloxan, is not the major pathway in this organism, if it occurs at all. Smith \& Emmart (1949), however, did observe a slight stimulation of riboflavin synthesis in Mycobacterium tuberculosis with both (I) and alloxan.

The absence of stimulation of riboflavin synthesis by 5:6-dimethylbenziminazole (there is actually a slight inhibition) and (I) also makes it very unlikely that in $E$. ashbyii, at least, the pathway for riboflavin biosynthesis is similar to that for the cobalamins in other micro-organisms, e.g. Escherichia coli, where both 4:5-dimethyl-o-phenylenediamine and riboflavin itself stimulate the biosynthesis of cyanocobalamin in a vitamin $B_{12}$ requiring mutant (Ford \& Holdsworth, 1954).

\section{General aspects of amino acid metabolism}

From the general point of view of amino acid metabolism, it is extremely interesting that serine is active in promoting flavinogenesis and glycine is not. Although glycine has been demonstrated to be the precursor of serine in many animal tissues and in some micro-organisms, e.g. Torulopsis utilis (Ehrensvärd, Sperber, Saluste, Reio \& Stjernholm, 1947), it seems that $E$. ashbyii cannot bring about this conversion. From a similar point of view the activity of L-tyrosine and the inactivity of Lphenylalanine suggests that the latter cannot be converted into the former in $E$. ashbyii. This would appear to fit in with recent work on Esch. coli (Simmonds, Tatum \& Fruton, 1947; Davis, 1950) which suggests that there are independent routes of synthesis of these two amino acids and that phenylalanine is not converted into tyrosine.

\section{SUMMARY}

1. Eremothecium ashbyii grown on a basal glucose-salts-vitamins medium supplemented with $0.24 \%(w / v)$ peptone is fully grown after 5 days but continues to produce riboflavin up to 7-8 days. Maximal concentration of riboflavin is obtained over the range $0 \cdot 16-0 \cdot 40 \%(\mathrm{w} / \mathrm{v})$ peptone.

2. Using the basal medium supplemented with $0.005 \%(w / v)$ peptone $\mathrm{N}$, addition of L-threonine, 
L-serine or L-tyrosine specifically stimulated riboflavin synthesis; L-tyrosine was the least effective. D-Threonine was inactive. L-Glutamate, L-aspartate and L-asparagine stimulated both growth and flavinogenesis, whilst L-cysteine inhibited both. Other amino acids tested were without obvious effect on riboflavin synthesis, but some inhibited growth slightly.

3. Under the same conditions the purines xanthine and adenine, and adenosine, stimulated flavinogenesis whilst most pyrimidines and their derivatives were without effect, although alloxan inhibited both growth and riboflavin synthesis. At very high concentrations, uracil inhibited riboflavin synthesis, although it did not inhibit the adenine-stimulated production of riboflavin.

4. Neither 5:6-dimethylbenziminazole nor 1:2dimethyl - 4 - amino - 5 - (D - 1' - ribitylamino) benzene stimulated riboflavin production under the same conditions.

5. Of the other nitrogen-containing compounds tested, urea in low concentrations occasionally stimulated and $\left(\mathrm{NH}_{4}\right)_{2} \mathrm{SO}_{4}$ was without effect. D-Glucosamine was a powerful inhibitor of both growth and riboflavin.

6. The effects of the stimulatory amino acids are not cumulative, whilst those of a purine and an amino acid are.

7. The significance of these results in relation to the problem of the biosynthesis of riboflavin is discussed.

We wish to thank Dr E.S. Holdsworth and Dr V. Petrow for generous gifts of chemicals.

We are also grateful to the Medical Research Council for financial assistance and to the Lancashire County Education Committee for a scholarship (S.P.).

\section{REFERENCES}

Adamson, D. C. M. (1948). Analyst, 73, 444.

Banerjee, S., Dittmer, K. \& du Vigneaud, V. (1945). Science, $101,647$.

Brown, G. B. (1953). Annu. Rev. Biochem. 22, 149.

Burkholder, P. (1943). Arch. Biochem. 3, 121.

Chin, C. (1947). J. Fermentation Tech. 25, 140.

Crammer, J. L. (1948). Nature, Lond., 161, 349.

Davis, B. D. (1950). Experientia, 6, 41.

Deseive, E. (1947). Milchwissenschaft, $2,141$.

Dulaney, E. L. \& Grutter, F. H. (1950). Mycologia, 42, 717.

Ehrensvärd, G., Sperber, E., Saluste, E., Reio, L. \& Stjernholm, R. (1947). J. biol. Chem. 169, 759.

Ford, J. E. \& Holdsworth, E. S. (1953). Biochem. J. 56, xxxv.

Goodwin, T. W. \& Pendlington, S. (1954). Biochem. J. 56, xxiv.

Guillermond, A., Fontaine, M. \& Raffi, A. (1935). C.R. Acad. Sci., Paris, 201, 1077.

Hickey, R. J. (1953). J. Bact. 66, 27.

Maclaren, J. A. (1952). J. Bact. 63, 233.

Peltier, G. L. \& Borchers, R. (1947). J. Bact. 54, 519.

Plaut, G. W. E. (1953a). Fed. Proc. 12, 254.

Plaut, G. W. E. (1953b). Abstr. Pap. Amer. Chem. Soc. no. $35 \mathrm{C}$.

Pridham, T. G. (1952). Econ. Bot. 6, 185.

Schopfer, W. H. (1944). Helv. chim. acta, 27, 1017.

Schopfer, W. H. \& Guilloud, M. (1945a). Experientia, $1,1$. Schopfer, W. H. \& Guilloud, M. (1945b). Schweiz. Z. Path. 8, 521.

Schopfer, W. H. \& Guilloud, M. (1945c). Experientia, 1, 333.

Simmonds, S., Tatum, E. L. \& Fruton, J. S. (1947). J. biol. Chem. 169, 91.

Smith, M. I. \& Emmart, E. W. (1949). J. Immunol. 61, 259.

Tanner, F. W., Vojnovich, C. \& van Lanen, J. M. (1949). J. Bact. 58, 737.

Wickerham, L. J., Flickinger, M. H. \& Johnston, R. (1946). Arch. Biochem. 9, 95.

Yaw, K. E. (1952). Mycologia, 44, 307.

\title{
On the Significance of $\gamma$-Glutamyl Transpeptidation in Peptide Biosynthesis
}

\author{
By R. W. HENDLER* AND D. M. GREENBERG \\ Department of Physiological Chemistry, University of California School of Medicine, Berkeley
}

(Received 3 November 1953)

Transpeptidation reactions have been receiving increasing emphasis in connexion with the syntheses of peptide and amide bonds and hence of proteins (Hanes, Hird \& Isherwood, 1950, 1952; Hanes, Connell \& Dixon, 1953; Waelsch, 1953; Fruton, Johnston \& Fried, 1951; Fruton, 1950). Particular interest attaches to the $\gamma$-glutamyl transpeptidation

* Present address: National Heart Institute, United States Public Health Service, Bethesda 14, Maryland.

Biochem. 1954, 57 reaction of Hanes et al. $(1950,1952)$ because the hypothesis has been advanced that glutamine and glutathione serve to direct the energy of the energy rich bonds of adenosine triphosphate into the formation of peptide bonds by means of the transpeptidation and transamidation reactions (Waelsch, 1953). The hypothesis further assumes that the $\gamma$-glutamyl peptides formed by these reactions would either rearrange to $\alpha$-peptides or by further exchanges 